\title{
ПРАВОВЕ РЕГУЛЮВАННЯ ВВІЗНОГО МИТА В УКРАЇНІ
}

Атаманчук Н. I.

Стаття присвячена аналізу ввізного мита в Україні. Автором розглянуто особливості правового регулювання ввізного мита в Україні, поняття ввізного мита, ознаки та функціі. Узагальнено переваги та недоліки використання імпортного мита в Україні та запропоновано шляхи вдосконалення податкового та митного законодавства. 3anponoновано авторське визначення поняття «ввізне мито».

Ключові слова: мито, ввізне мито, Митний кодекс України, Податковий кодекс України, Світова організація торгівлі, Європейський Союз.

Статья посвящена анализу ввозной пошлины в Укра ине. Автором рассмотрены особенности правового регулирования ввозной пошлины в Украине, понятие ввозной пошлины, признаки и функции. Обобщены преимущества и недостатки использования импортной пошлины в Украине и предложены пути совершенствования налогового и таможенного законодательства. Предложено авторское определение понятия «ввозная пошлина».

Ключевые слова: пошлина, ввозная пошлина, Таможенный кодекс Украины Налоговый кодекс Украины, Всемирная торговая организация, Европейский Союз.

An import duty is the type of duty that is used in Ukraine. Importance of import duty in Ukraine consists in that this tax fills the State budget of Ukraine not only, and also carries out adjusting of economy and defense of national commodity producer.

Consider the signs of import duty: necessity of inpayment in connection with the import of commodities on custom to territory of Ukraine; including of size of import duty to the cost of commodity, and as a result of increase of cost of commodity; speed of receipt is from an inpayment; high probability of receipt; regulative influence is on a payer from the side of the state (through introduction of import duty, establishment of rates, increase or reduction to the size of rates, input of privileges and others like that); an inpayment is in a money form; irreversibility of payment is for a payer; an inpayment is in the terms envisaged in a normatively-legal act; publicity of tax.

The functions of import duty are: fiscal (filling of profitable part of budget), regulation (establishment of economic barriers is to the import of certain categories of commodities on custom territory of Ukraine, defense of internal user market, and also settlement and improvement of structure of import), stimulant (envisages creation of pre-conditions for the increase of import of country).

Legislative determination of concept of import duty is not perfect, not in a complete measure exposes essence, signs and features of this tax, for this reason, and needs certain clarification and making alteration to Custom Code of Ukraine. To that end, suggest to make alteration to the article 272 of Custom Code of Ukraine in the existent concept of import duty and to expound in a next release: a import duty is a national, obligatory, indirect tax on commodities that is brought in on custom territory of Ukraine, joins in the cost of such commodities, set, counted and paid in accordance with the Custom code of Ukraine, laws of Ukraine and international agreements, a consent to obligatoryness of that is given by Verkhovna Rada.

Key words: duty, import duty, Custom code of Ukraine, Internal revenue code of Ukraine, World organization of trade, European Union.
Постановка проблеми та їі актуальність. Актуальність дослідження обумовлена необхідністю визначення сутності ввізного мита, його поняття, виділення його ознак та особливостей. Важливість ввізного мита в Україні полягає у тому, що цей податок не лише наповнює Державний бюджет України, але й здійснює регулювання економіки та захист національного товаровиробника. Саме тому сьогодні багато питань щодо теоретичних ы практичних засад функціонування ввізного мита залишаються дискусійними та потребують ґрунтовного аналізу.

Аналіз останніх досліджень і публікацій. Питання митного оподаткування досліджувало багато науковців як вітчизняних, так і зарубіжних, а саме: В. Андрущенко, Р. Войткович, Є. Волков, О. Гребельник, І. Дюмулєн, А. Дрига, П. Пашко, І. Луніна, В. Суторміна, В. Федоров, Н. Фролов та інші. Однак, незважаючи на значні здобутки вчених, ґрунтовнішого вивчення потребує питання щодо ввізного мита в умовах реформування податкового та митного законодавства.

Виклад основного матеріалу. Відповідно до ст. 271 Митного кодексу України (далі - МКУ) [1], мито це загальнодержавний податок, встановлений Податковим кодексом України та цим Кодексом, який нараховується та сплачується відповідно до МКУ, законів України та міжнародних договорів, згода на обов'язковість яких надана Верховною Радою України. В Україні застосовуються такі види мита як: ввізне мито, вивізне мито, сезонне мито, особливі види мита: спеціальне, антидемпінгове, компенсаційне, додатковий імпортний збір. Статтею 272 МКУ визначено, що ввізне мито встановлюється на товари, що ввозяться на митну територію України. Встановлення нових та зміна діючих ставок ввізного мита, визначених Митним тарифом України, здійснюються Верховною Радою України шляхом прийняття законів України. Регламентом Європейського Парламенту і Ради (ЄС) № 952/2013 від 9 жовтня 2013 року про встановлення Митного кодексу Союзу ввізне мито означає мито, що підлягає сплаті за ввіз товарів [2].

За даними Державної казначейської служби України у середньому $97 \%$ усього мита надходить саме від ввізного мита. Щомісячно до спеціального фонду Державного бюджету зараховується близько 0,3 млрд грн ввізного мита за нафтопродукти, транспортні засоби та шини до них [3].

Платниками ввізного мита відповідно до статті 276 МКУ $\epsilon: 1)$ особа, яка ввозить товари на митну територію України у порядку та на умовах, встановлених цим Кодексом; 2) особа, на адресу якої надходять товари, що переміщуються (пересилаються) у міжнародних поштових або експрес-відправленнях, несупроводжуваному багажі, вантажних відправленнях; 3) особа, на яку покладається обов'язок дотримання вимог митних режимів, які передбачають звільнення від оподатку- 
вання митом, у разі порушення таких вимог; 4) особа, яка використовує товари, митне оформлення яких було здійснено з умовним звільненням від оподаткування, не за цільовим призначенням та/або всупереч умовам чи цілям такого звільнення згідно з цим Кодексом, іншими законами України, а також будь-які інші особи, які безпідставно використовують звільнення від оподаткування митом (податкову пільгу); 5) особа, яка реалізує або передає у володіння, користування чи розпорядження товари, що були випущені у вільний обіг на митній території України із звільненням від оподаткування митними платежами, до закінчення строку, визначеного законом; 6) особа, яка реалізує товари, транспортні засоби відповідно до МКУ [1].

Необхідно зазначити, що об'єктами оподаткування ввізним митом виступають товари, митна вартість яких перевищує еквівалент 150 євро, що ввозяться на митну територію України підприємствами; товари, що ввозяться (пересилаються) на митну територію України в обсягах, які підлягають оподаткуванню митними платежами відповідно до розділу XII МКУ, а також розділів V та VI ПКУ; товари, транспортні засоби, що реалізуються відповідно до статті 243 МКУ [1, ст. 277].

Датою виникнення податкових зобов'язань із сплати мита у разі ввезення товарів на митну територію України $є$ дата подання органу доходів і зборів митної декларації для митного оформлення або дата нарахування такого податкового зобов' язання органом доходів і зборів у випадках, визначених МКУ та законами України [1, ст. 278].

При цьому, базою оподаткування ввізним митом товарів, що переміщуються через митний кордон України, $є: 1)$ для товарів, на які законом встановлено адвалорні ставки мита, - митна вартість товарів; 2) для товарів, на які законом встановлено специфічні ставки мита, - кількість таких товарів у встановлених законом одиницях виміру [1, ст. 279 ].

Щодо тарифних пільг, то у відповідності до статті 281 МКУ допускається встановлення тарифних пільг (тарифних преференцій) щодо ставок Митного тарифу України у вигляді звільнення від оподаткування ввізним митом, зниження ставок ввізного мита або встановлення тарифних квот відповідно до законодавства України та для ввезення товарів, що походять 3 держав, з якими укладено відповідні міжнародні договори. Тарифні квоти у вигляді встановлення обсягів окремих товарів, призначених для ввезення на митну територію України у визначений період зі зниженням ставки ввізного мита, встановлюються окремими законами. Ввезення товарів на митну територію України поза тарифними квотами здійснюється без зниження ставок ввізного мита [1].

Окрім того, стаття 282 МКУ визначає звільнення від оподаткування митом так звані - податкові пільги [1]. Прикладом є зареєстрований у Верховній Раді законопроект № 9458 від 28 грудня 2018 року [5], яким пропонується внесення змін до Митного Кодексу України в частині розміру пільгових ставок ввізного мита на пряжу. Зокрема, пропонується встановлення пільгової ставки ввізного мита 0\% на наступні товарні позиції: пряжа однокручена або багатокручена; змішана головним чином або винятково з бавовною. На думку авторів законопроекту, запропоновані зміни дадуть позитивний ефект для галузі та соціально-економічного розвитку
України в цілому, зокрема у вигляді створення додаткових робочих місць, зростання рівня зайнятості населення, збільшення відрахувань і валютних надходжень до бюджету, зростання галузевого вкладу в економіку держави.

Окрім того, законодавством передбачено звільнення від оподаткування ввізним митом залежно від обраного митного режиму, зокрема, товарів, поміщених у митний режим реімпорту та відмови на користь держави [1, ст. 283]. Також законодавством визначені особливості оподаткування митом деяких товарів, а саме: гуманітарної допомоги, товарів Червоного Хреста України, проекту наукового парку, які звільняється від оподаткування ввізним митом [1, ст. 287].

Для прикладу, Парламентом ухвалено Закон України «Про внесення змін до Митного кодексу України щодо спрощення ввезення продукції оборонного призначення» від 2 вересня 2014 року № 1657-VII [6], яким спрощено ввезення продукції оборонного призначення на митну територію України під час дії особливого періоду, введення надзвичайного стану та у період проведення антитерористичної операції шляхом звільнення від оподаткування митом продукції оборонного призначення, за переліком, що встановлюється Кабінетом Міністрів України .

Також Президентом було підписано Закон України «Про внесення змін до Митного кодексу України щодо уточнення деяких положень» від 19 червня 2018 року № 2464-VIII [7], яким доповнюються чинні норми МКУ щодо звільнення від оподаткування ввізним митом спеціальних засобів індивідуального захисту; ниток та тканин (матеріалів) для виготовлення бронежилетів та шоломів; лікарських засобів та медичних виробів на період здійснення заходів із забезпечення національної безпеки і оборони, відсічі і стримування збройної агресії Російської Федерації у Донецькій та Луганській областях, що здійснюються шляхом проведення операції Об'єднаних сил.

Необхідно зазначити, що 5 лютого 2008 року Україна вступила до Світової організації торгівлі (далі - СОТ), ратифікувавши Протокол вступу Законом України від 10 квітня 2008 року № 250-VI [8], що дає змогу більш повною мірою реалізувати національні конкурентні переваги у міжнародній торгівлі та досягнути вищого рівня розвитку вітчизняної економіки. У зв'язку з цим розпочато процес приведення національного законодавства відповідно до вимог СОТ, зокрема щодо митно-тарифного регулювання. Зокрема, пункт 5 статті 280 МКУ передбачено, що ввізне мито $є$ диференційованим щодо товарів, що походять з держав, які спільно з Україною входять до митних союзів або утворюють з нею зони вільної торгівлі. У разі встановлення будь-якого спеціального преференційного митного режиму згідно з міжнародними договорами, згода на обов'язковість яких надана Верховною Радою України, застосовуються преференційні ставки ввізного мита, встановлені Митним тарифом України. До товарів, що походять з України або з держав-членів Світової організації торгівлі, або з держав, з якими Україна уклала двосторонні або регіональні угоди щодо режиму найбільшого сприяння, застосовуються пільгові ставки ввізного мита, встановлені Митним тарифом України, якщо інше не встановлено законом [1].

Окрім того, Україна, підписавши Угоду про асоціацію між Україною, з однієї сторони, та $Є С$ з іншої 
сторони, яка 1 вересня 2017 року набула чинності у повному обсязі, створила зону вільної торгівлі між Україною та $€ С$, зі скасуванням ввізного мита на більшість товарів, що імпортуються на ринки один одного. Статтею 29 розділу IV Угоди про асоціацію між Україною та ЄC передбачено, що з моменту набрання нею чинності кожна Сторона зменшить або анулює ставки ввізного мита на певні товари походженням з іншої Сторони відповідно до графіків, встановлених у додатку І-А до цієї Угоди [9].

Сам графік зниження ставок мита 3 зазначенням коду УКТ ЗЕД зазначено в Додатку І-А до глави 1 (частина 1 - Тарифний графік України) та Додатку I-А до глави 1 (частина 2 - Тарифний графік ЄС). Для цілей глави 1 розділу IV Угоди «походження» означає, що товар підпадає під правила походження, викладені в Протоколі 1 до цієї Угоди («Щодо визначення концепції «походження товарів» і методів адміністративного співробітництва») (далі - Протокол 1). Відповідно до пункту 1 статті 16 Протоколу 1 товари, що походять з ЄС, i товари, що походять з України, після ввезення до України чи ЄС, відповідно, підпадають під дію Угоди за умови подання одного з таких документів.

Необхідно зазначити, що Міністерство економічного розвитку і торгівлі України традиційно за 100 днів до початку нового року, публікує рівні ставок ввізного мита України, які будуть застосовуватись по відношенню до імпорту товарів походженням з ЄС в рамках зони вільної торгівлі. Це дає можливість українському бізнесу планувати свою діяльність на наступний рік. Зокрема, згідно з документом у 2019 до імпорту живих тварин для забою застосовуватиметься ставка ввізного мита в 1,7\%, до туш та половини туш тварин - 0\%; до помідорів, капусти (цвітної і брокколі, брюссельської), гороху, квасолі - 6,67\%, до картоплі - 0\% [10].

Окрім того, Законом України «Про застосування спеціальних заходів щодо імпорту в Україну» від 22 грудня 1998 року № 332-XIV [11] з метою запровадження механізмів захисту інтересів національного товаровиробника регулюються засади і порядок порушення та проведення спеціальних розслідувань фактів зростання імпорту в Україну незалежно від країни походження та експорту товару, що заподіює значну шкоду або загрожує заподіянням значної шкоди національному товаровиробнику, за результатами яких можуть застосовуватися спеціальні заходи. Такими заходами можуть бути: запровадження режиму квотування імпорту в Україну, що $є$ об'єктом спеціального розслідування, з визначенням обсягів квот та порядку їх розподілу та установлення спеціального мита щодо імпорту в Україну, який є об'єктом спеціального розслідування [11, ст. 16].

Поділяємо думку вчених [12, с. 70; 13, с. 732] щодо того, що на сьогодні в Україні $\epsilon$ низка проблем, які впливають на стан тарифного регулювання, що відповідно вплинуло на обсяги стягнення мита, а саме: наявність значної кількості пільг зі сплати ввізного мита для окремих галузей та суб'єктів зовнішньоекономічної діяльності; встановлення специфічних та комбінованих ставок ввізного мита без урахування специфіки поставок товару; відставання митного контролю від сучасних потреб пропускної здатності та світових стандартів контролю товарів; значна деталізація та надмірна диференціація у розмірах ставок ввізного мита на однорідні товари; корупційні діяння в митних органах призводять до зменшення надходжень до державного бюджету; ігнорування галузевими міністерствами та відомствами основних принципів і підходів щодо підготовки законодавчих актів з питань тарифного регулювання.

Н.М. Левченко зазначає, що на сьогодні одним із головних наукових інструментів щодо роз' яснення наслідків впливу імпортного мита на економіку країни виступає відома концепція аналізу рівня добробуту суспільства (welfare analysis). Вчений пише, що розмір чистих збитків для суспільства через запровадження імпортного тарифу не стільки пояснюється абсолютною величиною самого мита, скільки він прямо пропорційно залежить як від еластичності Qпропозиції, так i Qпопиту. Інакше кажучи, чим більш похилими $є$ криві пропозиції і попиту (чим більший кут їх нахилу), тим більшими будуть втрати вітчизняних споживачів і виробників товарів [14].

Однак беззаперечним $\epsilon$ той факт, що максимальна вигода для суспільства країни досягається за умови вільної міжнародної торгівлі, коли урядами держав не вживається жодних заходів протекціонізму (принцип вільної торгівлі). Проте в сучасній світовій економіці такий принцип $\epsilon$ швидше абстрактно-теоретичним, ніж практично-реальним. За ситуації, коли одна держава активно захищає внутрішній ринок від іноземної конкуренції, використовуючи цілу низку зовнішньоторговельних обмежень (тарифних і кількісних) та застосовуючи заходи щодо покращання процесу просування вітчизняних товарів на світовий ринок (експортні субсидії, демпінгові ціни тощо), дотримання курсу на повну лібералізацію торгівлі $\epsilon$ необґрунтованим і нераціональним кроком. Навпаки, за таких умов уряд держави має виявити той оптимальний рівень тарифного захисту, який би дозволив отримати найбільший позитивний ефект для громадян цієї країни [14].

Вітчизняні вчені вважають, що задля збільшення надходження митних платежів доцільно було б провести уніфікацію порядку справляння мита; посилити контроль органів державної влади над стягненням митних платежів і наданням митних пільг задля протидії корупційним схемам і тіньовому бізнесу, введення чіткого і прозорого механізму застосування спрощеного порядку проведення процедур митного оформлення та розширення прав митних органів, удосконалення комунікативної політики та введення широкого кола інформаційних каналів взаємодії між Державною фіскальною службою України та платниками податку щодо адміністрування мита [15, с. 116-117].

Висновки.

1. Законодавче визначення поняття ввізного мита не $\epsilon$ досконалим, не в повній мірі розкриває сутність, ознаки та особливості даного податку, саме тому, на нашу думку, потребує певного уточнення та внесення змін до МКУ. 3 цією метою пропонуємо внести зміни до статті 272 МКУ в наявне поняття ввізного мита та викласти у наступній редакції: «ввізне мито - загальнодержавний, обов'язковий, непрямий податок на товари, що ввозяться на митну територію України, включається до ціни таких товарів, встановлюється, нараховується та сплачується відповідно до Митного кодексу України, законів України та міжнародних договорів, згода на обов'язковість яких надана Верховною Радою України».

2. Ознаками ввізного мита вважаємо: необхідність сплати у зв'язку з ввезенням товарів на митну території України; включення розміру ввізного мита до ціни това- 
ру, і як наслідок збільшення вартості товару; швидкість надходження від сплати; висока ймовірність надходження; регулюючий вплив на платника з боку держави (через введення ввізного мита, встановлення ставок, збільшення чи зменшення розміру ставок, запровадження пільг та преференцій тощо); сплата у грошовій формі; безповоротність платежу для платника; сплата в строки, закріплені в нормативно-правовому акті; публічність податку тощо.

3. Функціями ввізного мита $є$ : фіскальна (наповнення дохідної частини бюджету), регулювальна (встановлення економічних бар'єрів для ввезення певних категорій товарів на митну територію України, захисту внутрішнього споживчого ринку, а також врегулювання та поліпшення структури імпорту), стимулююча (передбачає створення передумов для збільшення імпорту країни).

4. Напрямами реформування податкового та митного законодавства щодо ввізного мита $\epsilon$ вдосконалення чинних ставок ввізного мита та запобігання імпорту товару, що призводить або може призвести до заподіяння серйозної шкоди національному виробнику.

\section{Література}

1. Митний кодекс України від 13 березня 2012 року № 4495-VI. URL: https: / /zakon.rada.gov.ua/laws/show/449517\#n2269. (дата звернення: 10.04.2019).

2. Регламент Європейського Парламенту і Ради (ЄC) № 952/2013 від 9 жовтня 2013 року про встановлення Митного кодексу Союзу. URL: https://zakon.rada.gov.ua/ laws/show/984_009-13/ed20131009\#n93. (дата звернення: 10.04.2019).

3. Мито: стан виконання за січень-червень 2018 року. Веб-сайт. URL: https://feao.org.ua/wp-content/ uploads/2018/08/customs_duties_budget_execution_in_ january-june_2018.pdf (дата звернення: 10.04.2019).

4. Про Митний тариф України : Закон України від 19 вересня 2013 року № 584-VII. URL: https://zakon.rada. gov.ua/laws/show/584-18\#n3. (дата звернення: 10.04.2019).

5. Проект Закону про внесення змін до Митного тарифу України, встановленого Законом України «Про Митний тариф України», щодо ставок мита на пряжу 9458 від 28 грудня. 2018 р. URL: http://w1.c1.rada.gov.ua/ pls/zweb2/webproc4_1?pf3511=65309 (дата звернення: 10.04.2019).

6. Про внесення змін до Митного кодексу України щодо спрощення ввезення продукції оборонного призначення : Закон України від 2 вересня 2014 року № 1657-VII.
URL: https://zakon.rada.gov.ua/laws/show/1657-vii. (дата звернення: 10.04.2019).

7. Про внесення змін до Митного кодексу України щодо уточнення деяких положень : Закон України від 19 червня 2018 року № 2464-VIII. URL: https://zakon.rada. gov.ua/laws/show/2464-19 (дата звернення: 10.04.2019).

8. Про ратифікацію Протоколу про вступ України до Світової організації торгівлі : Закон України від 10 квітня 2008 року № 250-VI. URL: https://zakon.rada.gov.ua/laws/ show/250-17 (дата звернення: 10.04.2019).

9. Угода про асоціацію між Україною, з однієї сторони, та Європейським Союзом, Європейським Співтовариством з атомної енергії і їхніми державами-членами, з іншої сторони від 30 листопада 2015 р. № 984_011. URL: http://zakon2.rada.gov.ua/laws/show/984_011 (дата звернення: 11.04.2019).

10. Ставки увізного мита України, які будуть застосовуватись у 2019 році до імпорту товарів походженням з ЄС. Офіційний веб-сайт Міністерства економічного розвитку і торгівлі України. URL: http://me.gov.ua/ Documents $/$ Detail?lang $=u k-U A \& i d=5 c a 4 f 65 c-e 1 a 7-43 a 1-$ 9684-05ce9beddd7f\&title=StavkiUviznogoMitaUkrainiYakiBudutZastosovuvatisU2019-RotsiDolmportuTovarivPokhodzhenniamZs. (дата звернення: 11.04.2019).

11. Про застосування спеціальних заходів щодо імпорту в Україну : Закон України від 22 грудня 1998 року № 332-XIV. URL: https://ips.ligazakon.net/document/view/ t980332?an=1825\&ed=2018_09_06. (дата звернення: 11.04.2019).

12. Товкун І.М. Особливості законодавчого регулювання експортно-імпортних операцій. Право та інновації. 2015. № 1 (9). С. 69-74.

13. Литвин Я.А. Непряме оподаткування в Україні: сучасний стан та напрями вдосконалення. Глобальні та національні проблеми економіки. 2016. Вип. 11. C. 728-733.

14. Левченко Н.М. Оптимізація ввізного мита - запорука ефективного державного регулювання імпорту м'яса. Теорія та практика державного управління. 2010. Вип. 4. C. 266-274.

15. Жмурко Н.В., Купровська Л.Р. Мито в системі регулювання зовнішньоекономічних відносин України. Східна Європа: економіка, бізнес та управління. 2017. Вип. 1 (06). С. 114-117.

Атаманчук Н. І., кандидат юридичних наук, доцент, доцент кафедри фінансового права Навчально-наукового інституту права Університету Державної фіскальної служби України 